\title{
VALDES LOCEKL,A PIENĀKUMS RĪKOTIES KAPITĀLSABIEDRĪBAS (DALĪBNIEKU) INTERESĒS
}

\author{
DUTY OF THE MANAGEMENT BOARD \\ MEMBER TO ACT IN INTERESTS OF COMPANY \\ (ITS SHAREHOLDERS)
}

\author{
Evija Novicāne, Dr. iur. cand. \\ Latvijas Universitātes Juridiskās fakultātes doktorante
}

\section{Summary}

The question in whose interests management board members should act while performing their duties is one of the most disputable aspects of corporate management. The aforementioned issue has also been reviewed in Latvian court practice, however, no clear answer to the question is provided, since considerations of court practice contain influences of shareholder primacy theory, as well as stakeholder theory and company theory. The author briefly describes the aforementioned theories, coming to the conclusion that the approach of company's interests should have precedence over others. Respectively, in the presence of conflicting shareholder or stakeholder (for instance, creditor, employee etc.) interests, a management board member should focus on the benefit for the company, instead of seeking a sensible balance and acceptable compromise between conflicting interests. The author is also critical regarding the issue of the duty of a board member to consider the interests of creditors, indicating that corporate management should "focus" on the legality of corporate conduct, economically reasonable action that conforms to sound commercial practice, instead of hypothetical creditor interest considerations.

Atslēgvārdi: valdes locekḷa civiltiesiskā atbildība, lojalitātes pienākums, dalībnieku interešu teorija, objektīvi ieinteresēto personu teorija, kapitālsabiedrības labākās intereses

Keywords: civil liability of management board member, duty of loyalty, shareholder primacy theory, stakeholder theory, best interests of the company

\section{Ievads}

Jautājums par to, kā interesēs valdes loceklim jāpilda amata pienākumi, ir viens no diskutētākajiem korporatīvās pārvaldības aspektiem. Proti, vēl aizvien trūkst vienprātības jautājumā par to, vai korporatīvajā pārvaldībā priekšroka ir dodama kapitālsabiedrības dalībnieku interesēm, kapitālsabiedrības kā patstāvīga tiesību subjekta interesēm vai objektīvi ieinteresēto personu (angḷu val. - stakeholders) interesēm. 
Minētais jautājums ir īpaši aktuāls Latvijā, ṇemot vērā to, ka Komerclikumā tas nav tieši regulēts. Turklāt runa ir ne tikai par to, kurai interešu teorijai dot priekšroku, bet arī par vairākuma dalībnieku un mazākuma dalībnieku interešu konfliktiem, jēdziena "kapitālsabiedrības labākās intereses" saturisko tvērumu, kā arī iespējamo kolīziju starp nošķirtās atbildības principu un valdes locekḷa pienākumu rēķināties ar kreditoru interesēm. Tādējādi ir būtiski minētos jautājumus aplūkot plašākā griezumā.

\section{Kapitālsabiedrības, tās dalībnieku vai objektīvi ieinteresēto personu intereses?}

Komerclikums tiešā veidā nesatur regulējumu par to, kā interesēs valdes loceklim jāpilda amata pienākumi. Lìdzīga situācija ir arī Vācijā un daudzās citās romāṇu-ǵermāṇu tiesību loka valstīs, savukārt anglosakšu tiesību loka valstīs šis aspekts lielākoties ir normatīvi regulēts. Piemēram, atbilstoši Lielbritānijas Sabiedrību likuma 172. panta pirmajai daḷai valdes locekḷa pienākumi jāpilda sabiedrības interesēs visu tās dalībnieku labā, ${ }^{1}$ bet atbilstoši Austrālijas Sabiedrību likuma 181. panta pirmajai daḷai valdes loceklim jārīkojas labā ticībā sabiedrības labākajās interesēs. ${ }^{2}$ Tomēr arī anglosakšu tiesību loka valstīs trūkst vienprātības par to, kurām interesēm korporatīvajā pārvaldībā ir noteicošā loma.

Jāteic, ka jautājums par to, kā interesēs valdes loceklim jāpilda amata pienākumi, ir viens no korporatīvās pārvaldības diskutētākajiem aspektiem. Komerctiesību doktrīnā pamatā tiek diskutēts par trīs alternatīvām: 1) kapitālsabiedrības dalībnieku interesēm, 2) kapitālsabiedrības kā patstāvīga tiesību subjekta interesēm un 3) objektivi ieinteresēto personu interesēm. ${ }^{3}$

Vēsturiski ḷoti liela ietekme ir bijusi tā dēvētajai kapitālsabiedrības dalībnieku interešu paradigmai, un tas zināmā mērā ir likumsakarīgi, jo 19. gadsimtā, lai gan tika atzìts, ka kapitālsabiedrība ir patstāvīgs tiesību subjekts, tā tomēr tika uztverta kā personu (dalībnieku) apvienība, nevis uzṇēmums. ${ }^{4}$ Pastāvot šādai uztverei, pašsaprotami tika uzskatīts, ka kapitālsabiedrības pārvalde ir īstenojama tās dalībnieku interesēs. Attiecīgi tika uzskatīts, ka korporatīvajā pārvaldībā nav jārēḳinās ar citu grupu (piemēram, darbinieku, kreditoru, klientu) interesēm, ja tas nedod labumu kapitālsabiedrības dalībniekiem. ${ }^{5}$ Vienlaikus jāatzīmēe, ka minētajā teorijā l,oti mainīgs ir bijis viedoklis par to, kas tad uzskatāms par kapitālsabiedrības dalībnieku interesēm. Lielākoties tās ir tikušas asociētas ar iespējami lielāku

1 Section 172 (1) of the UK Companies Act 2006: "to promote the success of the company for the benefit of its members as a whole”. Pieejams: https://www.legislation.gov.uk/ukpga/2006/46/section/172 [aplūkots 06.02.2019.].

2 Section 181 (1) of the Australian Corporations Act 2001: "in good faith in the best interests of the corporation and for a proper purpose.” Pieejams: https://www.legislation.gov.au/Details/C2018C00424 [aplūkots 06.02.2019.].

3 Benedict Sh., Feaver D. Directors' Legal Duties and CSR: Prohibited, Permitted or Prescribed in Contemporary Corporate Law? The Dalhousie Law Journal, 2014, p. 8.

4 Sealy L. S. Directors' Wider Responsibilities - Problems Conceptual, Practial and Procedural. Monash University Law Review, 1987, Vol. 13, p. 165.

5 Ibid., p. 187. 
pel̦nas gūšanu, lai gan mūsdienās šādai nostājai, kā arī dalībnieku interešu teorijai kopumā ir veltīts daudz kritikas. ${ }^{6}$

Līdztekus dalībnieku interešu teorijai jau kopš 20. gadsimta 30. gadiem ir tikusi attīstīta arī tā dēvētā stake-holding (objektīvo interešu) teorija, rosinot diskusiju par to, vai korporatīvās vadības stūrakmens ir kapitālsabiedrības dalībnieku intereses vai tomēr ievērojami plašāks interešu loks, piemēram, darbinieku, kreditoru, piegādātāju, klientu, vides un vispārējās sabiedrības intereses. ${ }^{7}$ Objektīvo interešu teorija (angḷu val. - stakeholder theory) būtisku nozīmi ir ieguvusi pēdējās divās desmitgadès, bet jo īpaši pēc globālās ekonomiskās krīzes, lai gan vēl aizvien trūkst vienotas izpratnes par šìs teorijas pamatkonceptu un virzienu, kā arī jēdziena "objektīvi ieinteresētās personas" saturisko tvērumu. ${ }^{8}$

Nenoliedzami jāpiekrīt objektīvo interešu teorijas postulētajai atziṇai, ka komercdarbība netiek īstenota atrauti no sociālās vides, un tādēl kapitālsabiedrības labklājība un attīstība ir saistīta ar dažādu aspektu mijiedarbību, tostarp arī plašāka personu loka, nevis tikai kapitālsabiedrības dalībnieku interešu apsvērumiem. Tomēr objektīvo interešu teorija neievieš skaidrību par to, kā valdes loceklim rīkoties, ja objektīvi ieinteresēto personu intereses ir pretrunīgas vai pat nesavienojamas. Teorijā tiek runāts par to, ka valdes loceklim šādā gadijjumā nepieciešams veikt vispusīgu dažādu interešu vērtējumu, nepieciešamības gadỉjumā meklējot saprātīgus kompromisus. Tomēr praksē šādai atziņai nav īpašas pievienotās vērtības, ņemot vērā to, ka nereti kompromiss starp konkurējošām interesēm nav iespējams. ${ }^{9}$

Mūsdienās par vadošo korporatīvajā pārvaldỉbā aizsargājamo interešu konceptu tiek uzskatīta tā dēvētā kapitālsabiedrības interešu teorija. ${ }^{10}$ Kapitālsabiedrības interešu prioritāte parasti tiek argumentēta ar apsvērumu, ka kapitālsabiedrība ir patstāvīgs tiesību subjekts, kuru valdes loceklis vada un pārstāv, pildot amata pienākumus; turklāt arī korporatīvā atbildība valdes loceklim ir kapitālsabiedrības, nevis tās dalíbnieku priekšā. ${ }^{11}$ Vienlaikus jāteic, ka komerctiesību doktrīnā trūkst vienprātības par jēdziena "kapitālsabiedrības intereses" saturisko tvērumu, tostarp nereti apšaubot to, vai kapitālsabiedrībai kā juridiskai fikcijai vispār var būt pašai savas intereses. ${ }^{12}$

N̦emot vērā savstarpēji pretrunīgās atziṇas par to, kādas intereses valdes loceklim jāievēro, vadot kapitālsabiedrību, likumsakarīgi rodas jautājums, kurai no interešu teorijām dot priekšroku. Latvijas tiesību literatūrā norādìts,

6 Sk., piemēram: Keay A. Shareholder Primacy in Corporate Law: Can It Survive - Should It Survive. European Company and Financial Law Review, 2010, Vol. 7, pp. 405-410; Borok T. A. Modern Approach to Redefining "in the Best Interests of the Corporation". Windsor Review of Legal and Social Issues, 2013, Vol. XV, pp. 134-135.

7 Marshall Sh., Ramsay I. Stakeholders and Directors' Duties: Law, Theory and Evidence. University of New South Wales Law Journal, 2012, Vol. 35 (1), pp. 292-293.

${ }^{8}$ Sk.: Brandt F., Georgiou K. Shareholders vs Stakeholders Capitalism. University of Pennsylvania Law School: Comparative Corporate Governance and Financial Regulation, 2016, pp. 6-8. Pieejams: https://scholarship.law.upenn.edu/cgi/viewcontent.cgi?article=1002\&context=fisch_2016 [aplūkots 06.02.2019.].

${ }^{9}$ Līdzīgi sk.: Keay A. Stakeholder Theory in Corporate Law: Has it Got What it Takes. Richmond Journal of Global Law \& Business, 2010, Vol. 9 (3), pp. 277-290.

10 Sk., piemēram: Deakin S., Koziol H., Riss O. (eds.). Directors' \& Officers (D\&O) Liability. In: Tort and Insurance Law. Vol. 36. Berlin, Boston: Walter de Gruyter, 2018, pp. 34, 439, 491-492, 889.

11 Sk.: Fleischer in: Münchener Kommentar zum Gesetz betreffend die Gesellschaften mit beschränkter Haftung: GmbHG. Band 2: $\$ \$ 35-52$. München: Verlag C. H. Beck, 2016, § 43, Rn. 157 f.

12 Sk., piemēram: Brandt F., Georgiou K. 2016, p. 21. 
ka valdes loceklim ir pienākums būt lojālam gan pret sabiedrību kā patstāvīgu tiesību subjektu, gan arī pret visu tās dalïbnieku ekonomiskajām interesēm. ${ }^{13}$ Šāda nostāja ir nostiprinājusies arī Latvijas tiesu praksē. Piemēram, Latvijas Republikas Augstākās tiesas Civillietu departamenta 2018. gada 23. novembra spriedumā lietā Nr. C26097912 (SKC-291/2018) norādìts, ka valdes loceklim kā sabiedrības dalībnieku uzticības personai, kuram uzticēta svešas mantas pārvaldīšana, jāsekmē sabiedrības mērḳu sasniegšana - dalībnieku ekonomisko interešu realizācija. Līdz ar to valdes locekḷiem ir pienākums būt lojāliem gan pret sabiedrību kā patstāvīgu tiesību subjektu, gan arī pret visu tās dalībnieku ekonomiskajām interesēm. Valdes loceklim kā uzticības personai, no vienas puses, ir jāmaksimizē sabiedrības pel̦n,a, no otras puses, jāsaglabā sabiedrības manta. ${ }^{14}$

Tādējādi, kā redzams, Latvijā noteiktos aspektos tiek atzītas visas iepriekš minētās teorijas. Proti, norāde par to, ka valdes loceklim jāsekmē sabiedrības mērķu sasniegšana - dalībnieku ekonomisko interešu realizācija un jāmaksimizē sabiedrības pel̦na -, liecina par dalïbnieku interešu teorijas ietekmi. Norāde par nepieciešamību būt lojālam pret sabiedrību kā patstāvīgu tiesību subjektu ir raksturīga sabiedrības interešu teorijai. Savukārt atziṇa, ka valdes loceklim jāatrod saprātīgs balanss starp pel̦nas maksimizēšanu un mantas saglabāšanu, liecina par objektīvo interešu teorijas ietekmi.

Tomēr šāda vienlaicīga dažādu teoriju aprobēšana nav atbalstāma, jo faktiski tā pieprasa valdes loceklim "sēdēt uz vairākiem krēsliem”. Turklāt, atzīstot, ka valdes loceklim ir pienākums rēḳināties gan ar kapitālsabiedrības, gan dalībnieku un kreditoru interesēm, trūkst skaidrības, kā valdes loceklim jārīkojas, ja ir pretrunas, piemēram, starp kapitālsabiedrības un tās dalïbnieku interesēm, vai arī pretrunas starp vairākuma dalībnieku un mazākuma dalībnieku interesēm. Sekojot komerctiesību doktrīnas aktualitātēm, būtu vēlams pārvērtēt, vai kapitālsabiedrības (un attiecīgi - arī korporatīvās pārvaldības) mērḳis ir pēc iespējas lielāka pel̦nas gūšana. Proti, mūsdienās par korporatīvās pārvaldības mērķi tiek atzìta pēc iespējas efektīva uzṇēmuma darbība un sekmīga ilgtermiņa attīstība, nevis sabiedrības pel̦ṇas maksimizēšana. ${ }^{15}$ Attiecīgi, pastāvot šādam korporatīvās pārvaldības mērķim, prioritārā nozīme uzṇēmuma vadībā būtu jāpiešķir kapitālsabiedrības kā patstāvīga tiesību subjekta interesēm.

Vienlaikus, protams, neapstrīdams fakts ir tas, ka kapitālsabiedrības un tās dalībnieku intereses parasti pārklājas - ja kapitālsabiedrība sekmīgi īsteno komercdarbību, labumu no tā gūst arī dalībnieki. Taču jāṇem vērā, ka atsevišknos gadijjumos kapitālsabiedrības intereses var atšķirties no tās dalībnieku interesēm. Respektīvi, būtisks ir situācijas konteksts, tostarp kapitālsabiedrības īstenotās komercdarbības veids, plānotās rīcības būtība, kā arī kapitālsabiedrības finansiālā situācija (piemēram, vai kapitālsabiedrība ir sekmīgas attīstības pilnbriedā vai

13 Strupišs A. Komerclikuma komentāri. III. Rīga: “A. Strupiša juridiskais birojs” SIA, 2003, 143.-144.lpp., 342. \$.

14 Latvijas Republikas Augstākās tiesas Civillietu departamenta 23.11.2018. spriedums lietā Nr. C26097912 (SKC-291/2018), [9] punkts. Pieejams: https://manas.tiesas.lv/eTiesasMvc/lv/nolemumi [aplūkots 06.02.2019.]. Lìdzīgi sk.: Latvijas Republikas Augstākās tiesas Civillietu departamenta 27.06.2014. spriedums lietā Nr. C04470710 (SKC-0038-14), [6.2] punkts. Pieejams: https://manas. tiesas.lv/eTiesasMvc/lv/nolemumi [aplūkots 06.02.2019.]; Latvijas Republikas Augstākās tiesas Civillietu departamenta 25.01.2012. spriedums lietā Nr. C29338106 (SKC-25/2012), 8.4. punkts. Pieejams: www.at.gov.lv/downloadlawfile/3130 [aplūkots 06.02.2019.].

15 Sk., piemēram: Keay A. Ascertaining the Corporate Objective: An Entity Maximisation and Sustainability Model. Modern Law Review, September 2008, Vol. 71 (5), pp. 685-688, 691-694. 
saskārusies ar finansiālajām grūtībām). Tādējādi būtu kḷūdaini uzskatīt, ka rīkoties kapitālsabiedrības interesēs ir tas pats, kas rīkoties kapitālsabiedrības dalībnieku interesēs. Drīzāk būtu pamats runāt par to, ka kapitālsabiedrības interešu vērā ņemšana parasti ir saistīta ar tās dalībnieku interešu apsvērumiem. Taču tas nebūt nenozīmē, ka pienākums rīkoties kapitālsabiedrības interesēs nozīmē pienākumu rūpēties tikai par kapitālsabiedrības dalībnieku interešu îstenošanu, ignorējot citu tiesību subjektu tiesiski pamatotās intereses. ${ }^{16}$ Gluži pretēji - ja dalïbnieku intereses neatbilst kapitālsabiedrības interesēm, valdes loceklim ir pienākums dot priekšroku kapitālsabiedrības interesēm. ${ }^{17}$

Tādējādi ir pamats teikt, ka kapitālsabiedrības dalībnieku intereses ir viens no centrālajiem kapitālsabiedrības interešu apsvēruma elementiem, tomēr atsevišķās situācijās (jo īpaši maksātspējas problēmu gadījumos) runa var būt arī par valdes locekḷa pienākumu rēḳināties ar citu personu tiesiski pamatotajām interesēm pat tad, ja tas nedod labumu kapitālsabiedrības dalībniekiem. Attiecīgi secināms, ka valdes loceklim, pildot amata pienākumus, jārūpējas par kapitālsabiedrības interešu īstenošanu, un tas lielākoties ir saistīts ar dalïbnieku interešu apsvērumiem, taču atkarībā no situācijas konteksta būtiska nozīme var būt arī citām tiesiski pamatotām interesēm.

\section{Dalībnieku kopuma interešu problemātika}

Kontekstā ar kapitālsabiedrības dalībnieku interešu apsvērumiem komerctiesību doktrīnā allaž tiek uzsvērts, ka runa ir par visu kapitālsabiedrības dalībnieku interesēm jeb dalībnieku kopuma interesēm. Taču šādas pamatnostādnes praktiskais izpildījums var izrādīties l̦oti sarežğìts, ṇemot vērā to, ka kapitālsabiedrības dalībnieku intereses var būtiski atšķirties. Lielākoties konfliktējošas intereses ir vairākuma dalībniekiem un mazākuma dalībniekiem, taču atšḳirīgas intereses var būt arī ilgtermiņa dalībniekiem un īstermiņa dalībniekiem. Turklāt diskutabls ir arī jautājums, vai vispār ir pamats runāt par kādu vienojošu interesi, kas būtu raksturīga visiem kapitālsabiedrības dalībniekiem. Proti, lai gan parasti kapitālsabiedrības dalībnieku intereses tiek asociētas ar pel̦nas gūšanu, jārēḳinās, ka dalībnieku intereses mēdz būt arī neekonomiska rakstura, piemēram, nolūks nodrošināt darba vietas, pakalpojuma vai preces pieejamību maznodrošinātām personām, attīstīt nekomerciālus projektus (vides attīrīšana, infrastruktūras objektu būvniecība u. tml.) vai īstenot labdarības projektus ar komercdarbības palīdzību. ${ }^{18}$

Situācijās, kad kapitālsabiedrības dalībniekiem ir dažādas, nereti pat konfliktējošas intereses, zelta vidusceḷa meklējumi var izrādīties ne vien ārkārtīgi sarežgìiti un tiesiski grūti pamatojami, bet arī neracionāli, raugoties no kapitālsabiedrības labklājības perspektīvas. Tādējādi, aktualizējoties jautājumam par kapitālsabiedrības dalībnieku kopuma interesēm, priekšroka būtu dodama kapitālsabiedrības kā patstāvīga uzṇēmuma interesēm, pamatā ar to domājot ilgtermiṇa ieguvumus kapitālsabiedrībai, nevis dalïbnieku kopuma interešu apsvērumiem. Citiem vārdiem, pastāvot dažādām dalībnieku interesēm, valdes loceklim ir jāfokusējas uz kapitālsabiedrības labumu, nevis jācenšas mēgénāt rast saprātīgu balansu un

${ }^{16}$ Līdzīgi sk.: Marshall Sh., Ramsay I. 2012, p. 298.

17 Sk.: Benedict Sh., Feaver D. 2014, p. 16.

18 Sk.: Mocsary G. A. Freedom of Corporate Purpose. Brigham Young University Law Review, 2016, Issue 5, pp. 1381-1389. 
pieṇemamu kompromisu starp dažādajām dalībnieku interesēm. ${ }^{19}$ Minētais attiecas arī uz tiem gadījumiem, kad konfliktē citu objektīvi ieinteresēto personu (darbinieku, kreditoru, klientu u. c.) intereses. ${ }^{20}$

\section{Kreditoru interešu apsvērumu problemātika}

Kopš 20. gadsimta 80. gadiem korporatīvās pārvaldības kontekstā arvien lielāku ietekmi iegūst tā saucamā kreditoru interešu teorija, kuras pamatdoma ir tāda, ka valdes loceklim, pildot amata pienākumus, ir jāṇem vērā arī kreditoru intereses, it īpaši, ja kapitālsabiedrība ir nonākusi finansiālo grūtību situācijā. Pēdējo gadu laikā šis teorijas ietekme ir jūtama arī Latvijā. Piemēram, Latvijas tiesu praksē ir atzìts, ka, sākoties sabiedrības finansiālajām grūtībām, kreditori kḷūst par galvenajām finansiāli ieinteresētajām personām sabiedrības darbībā, un tādēḷ valdes loceklim ir pienākums nodrošināt kapitālsabiedrības mantas saglabāšanu un nepiel̦aut objektīi nepamatotu saistību pieaugumu, lai varētu segt kreditoru prasījumus pēc iespējas lielākā apmērā. ${ }^{21}$

Tomēr jāteic, ka jautājums par valdes locekḷa pienākumu ņemt vērā kreditoru intereses ir saistīts ar daudziem diskutabliem aspektiem. Tā, pirmkārt, komerctiesību doktrīnā nav vienprātības par to, kurā brīdī kapitālsabiedrības finansiālās grūtības rada valdes loceklim pienākumu ņemt vērā kreditoru intereses (respektīvi, vai runa ir par faktisko maksātnespēju, iespējamo maksātnespēju vai finansiālo nestabilitāti). Otrkārt, diskutabls ir arī jautājums par šì pienākuma saturisko tvērumu, it ipaši, ja kapitālsabiedrības kreditoriem ir konfliktējošas intereses. Treškārt, viedokḷi dalās par to, ciktāl runa ir par valdes locekḷa pienākumu veikt aktīvas darbības, proti, vai valdes loceklim ir jārūpējas par kreditoru interešu aizsardzību, vai pietiek tikai ar kreditoru interešu vērā ṇemšanu. ${ }^{22}$

Taču visdiskutablākais ir jautājums par to, ciktāl valdes locekḷa pienākums rēḳināties ar kreditoru interesēm ir savienojams ar nošķirtās atbildības principa ideju. Proti, jāṇem vērā, ka kapitālsabiedrība ir patstāvīgs tiesību subjekts, un atbilstoši nošķirtās atbildības principam par kapitālsabiedrības saistībām atbild kapitālsabiedrība ar visu savu mantu, nevis tās dalībnieki vai amatpersonas. Vienlaikus neapstrīdams fakts ir arī tas, ka atbilstoši vispārējam principam ikvienam (arī valdes loceklim) ir jāatbild par savas rīcības rezultātā nodarìto kaitējumu. ${ }^{23}$ Tādējādi valdes locekḷa civiltiesiskās atbildības kontekstā jautājums par valdes locekḷa pienākumu rēķināties ar kreditoru interesēm ir l̦oti neviennozīmīgs, tādēl kreditoru interešu teorija ir izpelnījusies kā atzinību, tā arī kritiku.

Atziņa, ka, īstenojot uzṇēmuma vadību, ir jāṇem vērā kreditoru intereses, parasti tiek pamatota ar apsvērumu, ka finansiālo grūtību gadījumā sabiedrības

${ }^{19}$ Lìdzīgi sk.: Benedict Sh., Feaver D. 2014, p. 24.

${ }^{20}$ Līdzīgi sk.: Keay A. Formulating a Framework for Directors' Duties to Creditors: An Entity Maximisation Approach. Cambridge Law Journal, 2005, Vol. 64 (3), pp. 614-646.

21 Sk.: Augstākās tiesas Civillietu departamenta 07.06.2016. spriedums lietā SKC-7/2016, [10] rindkopa; Augstākās tiesas Civillietu departamenta 29.12.2017. spriedums lietā Nr. C04254513 (SKC-351/2017), [7] rindkopa. Anonimizēto nolēmumu datubāze. Pieejams: https://manas.tiesas.lv/éTiesasMvc/nolemumi [aplūkots 06.02.2019.].

${ }^{22}$ Langford R. T. Best Interests: Multifaceted but Not Unbounded. Cambridge Law Journal, 2016, Vol. 75 (3), p. 515.

${ }^{23}$ Lìdzìgi sk.: Stace V. Directors' Liability in Negligence - Challenging the "Elements of the Tort" Approach. Victoria University of Wellington Law Review, 2016, Vol. 47 (3), p. 500. 
komercdarbība faktiski tiek îstenota uz kreditoru naudas rēkina, turklāt kreditoriem ir ḷoti ierobežotas iespējas ietekmēt korporatīvo pārvaldību. Tādējādi kreditoru interešu teorijas aizstāvji norāda, ka valdes locekḷa pienākums kapitālsabiedrības vadībā rēķināties ar kreditoru interesēm nodrošina taisnīgumu un pēc iespējas piln̄̄gāku kreditoru prasījumu segšanu kapitālsabiedrības maksātnespējas gadījumā. ${ }^{24}$

Tomēr jāatzīst, ka kreditoru interešu teorijai netrūkst kritiķu. Piemēram, kā pretarguments tiek minēts līgumu brīvības princips - atbilstoši tam kreditoram ir iespēja pašam parūpēties par savu interešu aizsardzību, vienojoties ar parādnieku par atbilstošiem līguma noteikumiem, pieprasot priekšapmaksu, prasijuma nodrošinājumu u. tml. Šādai nostājai gan nevar piekrist, jo ne visiem kreditoriem ir tik liela tirgus vara, lai varētu diktēt tādus līguma noteikumus, kas tos pilnībā pasargātu no saistību neizpildes riska. ${ }^{25}$ Tādējādi līgumu brīīibas princips drīzāk ir spekulatīvs, nevis racionāls arguments jautājumā par to, ciktāl valdes loceklim korporatīvajā pārvaldībā jārēḳinās ar kreditoru interešu apsvērumiem.

Vienlaikus jāteic, ka iebildumiem pret kreditoru interešu vērā n̦emšanu ir arī zināms pamats. Proti, raugoties no biznesa ètikas perspektīvas, valdes loceklim nenoliedzami ir lietderīgi apsvērt, kā iecerētā rīcība ietekmēs kapitālsabiedrības spēju izpildīt tās saistības. Tomēr šiem apsvērumiem ir jāatbilst nošķirtās atbildības principam jeb pamatnostādnei par to, ka kapitālsabiedrība par tās saistībām atbild ar savu mantu. Respektīivi, jāpatur prātā, ka kapitālsabiedrība kā uzṇēmējdarbības forma tika ieviesta nolūkā radìt mākslīgu barjeru starp tās dibinātājiem un kreditoriem, paredzot kreditoriem tiesibas saṇemt prasijuma izpildijumu tikai no kapitālsabiedrības mantas. Lìdz ar to var piekrist profesora Leonarda Sīlija (Leonard Sedgwick Sealy) viedoklim: kapitālsabiedrība kā uzñēmējdarbības forma nekad nebūtu piedzīvojusi uzplaukumu, ja jau pirms pusotra gadsimta korporatīvajā pārvaldībā tik būtiska loma tiktu piešķirta kreditoru interešu apsvērumiem. ${ }^{26}$

Vērtējot kreditoru interešu teoriju, rodas jautājums, vai patiesi korporatīvās pārvaldības kontekstā ir nepieciešams runāt par valdes locekḷa pienākumu ṇemt vērā kreditoru intereses. Drīzāk priekšroka būtu dodama nostādnei par to, ka valdes loceklim jārūpējas par kapitālsabiedrības interešu îstenošanu, kas atsevišķos gadījumos var nozīmēt arī nepieciešamību rēķināties ar kreditoru interesēm. Piemēram, jāṇem vērā, ka nerēķināšanās ar kreditoru interesēm var novest pie kapitālsabiedrības maksātnespējas, taču šāds scenārijs, domājams, nav savienojams ar kapitālsabiedrības interesēm. ${ }^{27}$ Turklāt kreditoru interešu aizsardzībai kalpo daudzas speciālās tiesību normas, kā arī no rūpības pienākuma izrietoša prasība rīkoties ekonomiski pamatoti un atbilstoši saprātīgai komerciālajai praksei. Tādējādi, lai valdes loceklis, pildot amata pienākumus, nenonāktu pretrunā ar nošķirtās atbildības principu, korporatīvās pārvaldības fokusam vajadzētu būt

${ }^{24}$ Sk., piemēram: Keay A. The Director's Duty to Take into Account the Interests of Company Creditors: When Is It Triggered? Melbourne University Law Review, 2001, Vol. 25 (2), p. 315.

25 Sk. plašāk: Keay A. Directors' Duties to Creditors: Contractarian Concerns Relating to Efficiency and Over-Protection of Creditors. The Modern Law Review, 2003, Vol. 66 (5), pp. 665-699.

${ }^{26}$ Citēts pēc: Hayne K. M. Directors' Duties and a Company's Creditors. Melbourne University Law Review, 2014, Vol. 38, pp. 813-814.

27 Sk.: Worthington S. Directors' Duties, Creditors' Rights and Shareholder Intervention. Melbourne University Law Review, 1991, Vol. 18, pp. 136-137. 
uz kapitālsabiedrības darbības likumību, ekonomiski attaisnojumu un saprātīgai komerciālajai praksei atbilstošu rīcību, nevis hipotētiskiem kreditoru interešu apsvērumiem. ${ }^{28}$

\section{Valdes locekḷa lojalitātes pienākums}

Valdes locekḷa pienākums rīkoties kapitālsabiedrības (dalībnieku) interesēs lielākoties tiek saistīts ar tā dēvēto lojalitātes pienākumu, lai gan komerctiesību doktrīnā trūkst vienprātības par lojalitātes pienākuma saturisko tvērumu. Pamatnostādne ir tāda, ka valdes locekḷa lojalitātes pienākums ir saistāms ar prasību amata pienākumus pildīt labā ticībā un pēc labākās sirdsapziņas rīkoties kapitālsabiedrības labā, nenostādot sevi situācijās, kurās viṇa personīgās intereses neatbilst kapitālsabiedrības interesēm. ${ }^{29}$ Tādējādi runa ir ne vien par valdes locekḷa pienākumu fokusēties uz kapitālsabiedrības ieguvumiem, bet arī par pienākumu atturēties negodprātīgi izmantot amata pilnvaras, piemēram, neizmantot amata pilnvaras pretēji komercdarbības būtībai vai personīgā labuma gūšanas nolūkā. ${ }^{30}$

Tomēr jāteic, ka valdes locekḷa lojalitātes pienākumam trūkst vienota koncepta, un praksē tas parasti tiek saistīts ar dažādiem apakšpienākumiem. Kā būtiskākos lojalitātes pienākuma aspektus var minēt valdes locekḷa pienākumu rīkoties kapitālsabiedrības labākajās interesēs, interešu konfliktu nepiel̦aujamību, konkurences aizliegumu, komercnoslēpuma glabāšanas pienākumu, aizliegumu izmantot kapitālsabiedrības mantu vai resursus (tostarp darījuma iespējas) personīgā labuma gūšanai, aizliegumu gūt neattaisnojamu labumu. ${ }^{31}$

Saistībā ar valdes locekḷa lojalitātes pienākumu viens no diskutablākajiem jautājumiem ir par to, kāda rīcība no valdes locekḷa ir sagaidāma, izvirzot prasību rīkoties kapitālsabiedrības labākajās interesēs. Tā pirmām kārtām nav vienprātības jautājumā par to, vai kapitālsabiedrības labāko interešu apsvērumi ir vērtējami tikai interešu konflikta nepiel̦aujamības kontekstā, vai tomēr runa ir par valdes locekḷa pienākumu rūpēties par noteikta ekonomiskā rezultāta sasniegšanu. Stingri nodalot lojalitātes pienākumu no rūpības pienākuma, nonākam pie secinājuma: kapitālsabiedrības labāko interešu apsvērumi nebūt nav saistāmi ar noteikta ekonomiska rezultāta sasniegšanu (tas ir rūpỉbas pienākuma aspekts). ${ }^{32}$ Tomēr komerctiesību doktrīnā trūkst konsekvences jautājumā par pienācīgu lojalitātes pienākuma un rūpības pienākuma nošķiršanu. Tādējādi lielākoties kapitālsabiedrības labāko interešu koncepts tiek saistīts ne vien ar interešu konfliktu nepiel̦aujamību, bet arī prasību sasniegt pēc iespējas labāku ekonomisko rezultātu.

${ }^{28}$ Līdzīgi sk.: Lombard S., Joubert T. The Legislative Response to the Shareholders V Stakeholders Debate: A Comparative Overview. Journal of Corporate Law Studies, 2014, Vol. 14, pp. 238-239; Worthington S. 1991, p. 142.

${ }^{29}$ Līdzīgi sk.: Langford R. T. 2016, p. 512; Lieder J. Die Treupflicht der Vorstandsmitglieder. TFM, 2016, Nr. 1, S. 42. Pieejams http://dergipark.gov.tr/download/article-file/270564 [aplūkots 14.02.2019.].

${ }^{30}$ Ratka T., Rauter R. (Hg.). Handbuch Geschäftsführerhaftung mit Vorstandshaftung. 2. Aufl. Wien: Facultas Verlags- und Buchhandels, 2011, Rn. 2/76.

31 Sk.: Münchener Kommentar zum Gesetz betreffend die Gesellschaften mit beschränkter Haftung: GmbHG, $₫ 43$, Rn. 152-198; Lieder J. 2016, S.43 f.; Rudāns S. Valdes locekḷa atbildība par sabiedrībai nodarītajiem zaudējumiem. Grām.: Komerctiesību aktuālie jautājumi Latvijā un Eiropā. Komercdarījumi. Atbildỉba. Komercstrīdi. Rīga: Tiesu namu agentūra, 2013, 190.-195. lpp.

32 Sk.: Worthington S. 1991, p. 132. 
Vienlaikus jāteic, ka komerctiesību doktrīnā nav vienprātības arīdzan par to, kāds ekonomiskais rezultāts ir uzskatāms par atbilstošu kapitālsabiedrības labākajām interesēm. Lai gan viedoḳ̣i dalās, lielākoties kapitālsabiedrības labāko interešu koncepts tiek saistīts ar valdes locekḷa pienākumu rīkoties ekonomiski pamatoti un atbildīgi, kā arī rūpēties par kapitālsabiedrības sekmīgu ilgtermiṇa attīstību. ${ }^{33}$

\section{Kopsavilkums}

1. Valdes loceklim, pildot amata pienākumus, jārūpējas par kapitālsabiedrības interešu īstenošanu, tas ir, pēc iespējas efektīvu uzṇēmuma darbību un sekmīgu ilgtermiṇa attīstību, un šāds koncepts vairumā gadījumu atbilst arīdzan kapitālsabiedrības dalībnieku interesēm, taču atkarībā no situācijas konteksta būtiska nozīme var būt arī citu subjektu (piemēram, kreditoru, darbinieku u. c.) tiesiski pamatotajām interesēm.

2. Pastāvot dažādām dalībnieku vai citu objektīvi ieinteresēto personu interesēm, valdes loceklim ir jāfokusējas uz kapitālsabiedrības labumu, nevis jācenšas mēǵināt rast saprātīgu balansu un pieņemamu kompromisu starp dažādajām interesēm.

3. Kreditoru interešu neievērošana nevar būt patstāvīgs pamats valdes locekḷa civiltiesiskajai atbildībai, bet var būt tikai pakārtots apsvērums situācijā, ja valdes loceklis nav nodrošinājis likuma prasību izpildi, rīkojies ekonomiski neattaisnojami vai neatbilstoši saprātīgai komerciālajai praksei.

4. Valdes locekḷa lojalitātes pienākums pamatā ir saistīts ar prasību rīkoties kapitālsabiedrības labākajās interesēs. Lai arī jēdziens "kapitālsabiedrības labākās intereses” ir atvērta tipa jēdziens, lielā mērā runa ir par valdes locekḷa pienākumu rīkoties ekonomiski pamatoti un atbildīgi, kā arī rūpēties par sekmīgu kapitālsabiedrības ilgtermiṇa attīstību.

33 Sk., piemēram: Deakin S., Koziol H., Riss O. 2018, p. 34; Lombard S., Joubert T. 2014, pp. 215-221, $225-228$. 